\title{
Synthesis of Phenyl-1,3,4-Thiadiazol-2-Amine Derivatives with in-Vitro Antioxidant Activity
}

\author{
Yasameen K. Al-Majedy*, Ali Mahdi
}

Branch of Chemistry, Department of Applied Science, University of Technology (UOT), Baghdad 10001, Iraq

\begin{tabular}{ll}
\hline \multicolumn{1}{c}{ Articles Information } & \multicolumn{1}{c}{ Abstract } \\
\hline Received: & In this research, the synthesis of structurally important antioxidants $7-$ \\
25.02 .2020 & Hydroxy-4-Methyl Coumarin (C1) and 4- Hydroxy Coumarin derivatives was \\
Accepted: & conducted. Coumarin was modified by various reaction steps for the production \\
26.04 .2020 & of target compounds. Different spectroscopic techniques characterized molecular \\
Published: & structures FT-IR ,NMR. Antioxidant activity was carried out against 1,1- \\
04.06 .2020 & diphenyl-2-picrylhydrazyl (DPPH) in vitro spectrophometric assays. Compared \\
Keywords: & to ascorbic acid, all compounds exhibited high antioxidant efficiency. Among \\
1,3,4-Thiadiazol & compounds, Compound 9 performance was considered to be the highest $(92 \%)$, \\
thiosemicarbazide & followed by compounds 8 and 10 (90\%). Ascorbic acid has been used as a \\
4- hydroxy coumarin & standard drug with inhibition of the percentage 90.5\%. \\
DPPH & \\
\hline
\end{tabular}

DOI: 10.22401/ANJS.23.2.05

* Corresponding author: yamin.chem79@gmail.com

\section{Introduction}

In the plant kingdom, coumarins consists of a fused aromatic chain to a pyron ring compressed [1]. Which coumarin was first isolated and used as a flavoring agent from tonka beans [2] it has functions such as anti-cancer activities [3]. antituberculosis [4] anti-HIV, antiviral [5] antialzheimer [6] and antimicrobial activities [7,8]. Thiazoles are known as heterocyclic moieties with a wide range of biological activities and their usefulness as a medicine has been well known [9]. Most thiazole derivatives physiological processes shown that they are active in fighting various diseases and that they are good antimicrobial activities [10]. Thiadiazoles are among the main heterocycles due to various biological activities, One of medicinal chemistry's privileged structural fragments. Antioxidants are substances capable of Protecting cells from damage from unstable molecules, known as free radicals. Antioxidants communicate with Free radicals and reinforce them, "beta-carotene, lycopene, vitamins C, E, A" and others [11]. An antioxidant is a molecule that can slow or prevent other molecules from oxidizing. Oxidation is a chemical reaction, transmitting electrons to an oxidant of a substance. Reactions could produce free radicals to oxidize that cause damaging cell chain responses. These chain responses are terminated by antioxidants by removing free intermediate radicals and by oxidizing themselves inhibit other oxidation responses. As a consequence, Antioxidants are often used reduce thiols, ascorbic acid, and polyphenols [11]. Antioxidants are becoming increasingly interested, especially in those designed to avoid the alleged Impacts on the human body of free radicals and the loss of fats and other food constituents. In both instances, antioxidants are preferred from natural sources rather than artificial [12]. This study aimed to identify the antioxidant activity of coumarin derivatives using the technique of $\mathrm{DPPH}$-free radical scavenging and $\left(\mathrm{H}_{2} \mathrm{O}_{2}\right)$ process. We concentrate on designing certain structural entities which integrate both of these molecules into a Single scaffold molecular. The first synthesis of the 5-(4-chlorophenyl)-1,3,4-thiadiazol-2-amine (1), 5-(4-bromophenyl)-1,3,4-thiadiazol-2-amine (2), The synthesis of new molecules 3-14 (Scheme 1) was then used as the starting material. 


\title{
Al-Nahrain Journal of Science
}

\author{
ANJS, Vol.23 (2), June, 2020, pp. 33 - 38
}

Scheme 1. The synthesized compound reaction sequences. $a=4$-Hydroxycoumarine; $b=7$-Hydroxy-4-Methyl Coumarin (C1); c= 2-Naphthol; d= Resorcinol.



$(7,8)$

\section{Materials and Methods}

\subsection{Chemistry}

The sequences of reactions for the synthesis of compounds 1-10 starting from aromatic aldehyde(4-chloro benzaldehyde, or 4-bromo benzaldehyde) are outlined in Scheme (1). 5-(4chlorophenyl)-1,3,4-thiadiazol-2-amine (1), and 5(4-bromophenyl)-1,3,4-thiadiazol-2-amine (2) was obtained from the reaction of aromatic aldehyde(4chloro benzaldehyde, or 4-bromo benzaldehyde) (0.04 mole) soluble in warm alcohol with thiosemicarbazide $(0.004$ mole $)$ soluble in hot water. The solution of aromatic aldehyde slowly applied to the solution of thiosemicarbazide with continuous stirring, white coloured solid (thiosemicarbazone) was formed which was extracted and recrystallized from 50\% aq.alcohol. Thiosemicarbazone $(0.005 m o l e)$ was suspended in
$150 \mathrm{~mL}$ of distilled water in a $500 \mathrm{~mL}$ beaker and ferric chloride (0.015mole) Was dissolved in distilled water with $150 \mathrm{~mL}$. The solution of thiosemicarbazone and ferric chloride were mixed in a round bottom flask and The temperature was 80-900C for 3 hours and was filtered hot. Added and stirred the solution is combined with citric acid and sodium citrate. After the whole solution has been cooled to room temperature, it was taken in a larger vessel (for volume growth) and with $10 \%$ aqueous ammonia neutralized. The precipitate obtained from $25 \%$ aqueous ethanol was filtered and recrystallized [13]. The residue were recrystallized from ethanol. Then compounds $(1,2)(0.01$ mole) a mixture of water $(4 \mathrm{~mL})$ and $\mathrm{HCl}$ $(2.25 \mathrm{~mL})$ was added. The solution will be stirred at (0-5) 0C for 10 minutes. Drop wise is added to a sodium nitrite solution $(0.69 \mathrm{gm}, 0.01 \mathrm{~mole})$ in 


\section{Al-Nahrain Journal of Science}

ANJS, Vol.23 (2), June, 2020, pp. 33 - 38

liquid $(2.5 \mathrm{~mL})$. Upon 10 minutes of stirring. The resulting diazonium salt solution has been added drop wise to a mixture of 4-Hydroxy coumarine , 4Methyl,7-hydroxy coumarine, 2-Naphthol, Resorcinol (1.22gm.,0.01mole) respectively in ethanol and $10 \% \mathrm{NaOH}(10 \mathrm{~mL})$ at $(0-5) 0 \mathrm{C}$ and $\mathrm{pH}$ $=5.5$. The mixture was stirred for another "20 minutes" after the addition was done. The resultant solid has been filtered off for 1 hour, dry and recrystallized with ethanol [14],

3-((5-(4-chlorophenyl)-1,3,4-thiadiazol-2-

yl)diazenyl)-4-hydroxy-2H chromen-2-one

3-((5-(4-bromophenyl)-1,3,4-thiadiazol-2-

yl)diazenyl)-4-hydroxy-2H-chromen-2-one

3-((5-(4-chlorophenyl)-1,3,4-thiadiazol-2-

yl)diazenyl)-7-hydroxy-4-methyl-2H-chromen-2-one

3-((5-(4-bromophenyl)-1,3,4-thiadiazol-2-

yl)diazenyl)-7-hydroxy-4-methyl-2H-chromen-2-one

1-((5-(4-chlorophenyl)-1,3,4-thiadiazol-2-

yl)diazenyl)naphthalen-2-ol

1-((5-(4-bromophenyl)-1,3,4-thiadiazol-2-

yl)diazenyl)naphthalen-2-ol

4-((5-(4-chlorophenyl)-1,3,4-thiadiazol-2-

yl)diazenyl)benzene-1,3-diol

4-((5-(4-bromophenyl)-1,3,4-thiadiazol-2-

yl)diazenyl)benzene-1,3-diol

\subsection{Radical Scavenging Operation (DPPH)}

Properties of antioxidant of derivatives of synthesized azo dye (1-10) have been tested using 2,2-diphenyl-1-picrylhydrazyl radical spectrophotometrically [15-17]. Originally, the different concentrations of $0.1 \mathrm{~mL}, 250,500,750$ and 1000 $\mu \mathrm{g} / \mathrm{mL}$ synthesized compounds and $1 \mathrm{~mL}$ of 0.2 $\mathrm{mM}$, DPPH with methanol dissolved with regular ascorbic acid. The mixture of The reaction has been incubated $280 \mathrm{C}$ for $30 \mathrm{~min}$ in the dark. Without the test samples, the control experiment was conducted as above. Use of the spectrophotometer UV-VIS, DPPH was calculated the absorption at $517 \mathrm{~nm}$. The DPPH radical scavenger was reduced determined using equation to the control's absorbance calculated.

$$
\text { Scavenging effect } \%=\frac{A_{0}-A_{1}}{A_{0}} \times 100
$$

Where A0 is the control reaction absorbance and A1 is the sample or standards absorbance.

\section{Results and Discussion}

In the synthesis of compounds(1-10), The structures of the target compounds are characterized by infrared spectroscopy IR ,NMR, $1 \mathrm{H}$ NMR spectra was measured on a Bruker Avance II 400 spectrometer, operating at $400 \mathrm{MHz}$ and TMS as an internal standard. the Physical properties of the compounds were show in (Table 1).The IR, $1 \mathrm{H}$ NMR of the synthesized compounds comply with the structures assigned (Table 2).

\subsection{Analysis of antioxidants}

Antioxidant activities of synthesized compounds in vitro were performed using assays against (DPPH).

\subsection{1. (DPPH) Scavenging Compound Activity (1- 10)}

The cell reinforcement exercises of mixes (1-10) have been tested in vitro utilizing DPPH rummaging strategies. The standard use of Ascorbic acid. Hydrogen-giving behavior, as calculated using DPPH radicals as acceptors of hydrogen, It has shown that was possible to find a significant correlation the degree of control between the grouping of the new ordered particle. DPPH mixes (1-10) have been appeared to diminish the steady radical. According to Figure $(1,2)$, The highest inhibition of compound 10 tested was the highest level At 1000 microns per mL (Figure 1). For compound 10, the highest performance scavenging operation was (90\%), followed by compound 9 (89\%). Ascorbic acid has been used as generic medicines with a percentage (90.5\%) inhibition. The compounds (8,9 and10) contain the $\mathrm{O}-\mathrm{H}$ group, This allows a resonancestabilized radical to be given by transition of hydrogen atom (HAT) to the free radical DPPH. The rummaging impact expanded with expanding groupings of the test mixes.

According to Fig. 1. the best DPPH scavengers were found to be compounds 3,4 and 5 possessing $75 \%, 73$ and $81 \%$ Radical function of DPPH scavenging. There is a hydroxyl phenyl ring in these compounds. Compounds with these replacements should have antioxidant activity [1823]. 


\section{Al-Nahrain Journal of Science}

ANJS, Vol.23 (2), June, 2020, pp. 33 - 38

Table 1. Physical properties of compounds (1-10)

\begin{tabular}{cccccc}
\hline $\begin{array}{c}\text { Compounds } \\
\text { No. }\end{array}$ & Molecular formula & Molecular weight (g/mol.) & Color & Yield (\%) & $\begin{array}{c}\text { Melting point } \\
\text { ('C) }\end{array}$ \\
\hline 1 & $\mathrm{C}_{8} \mathrm{H}_{6} \mathrm{ClN}_{3} \mathrm{~S}$ & 211.67 & Yellow & 55 & $220-222$ \\
2 & $\mathrm{C}_{8} \mathrm{H}_{6} \mathrm{BrN}_{3} \mathrm{~S}$ & 256.12 & Dark yellow & 56 & $218-210$ \\
3 & $\mathrm{C}_{17} \mathrm{H}_{9} \mathrm{ClN}_{4} \mathrm{O}_{3} \mathrm{~S}$ & 384.80 & Orang & 60 & $125-127$ \\
4 & $\mathrm{C}_{17} \mathrm{H}_{9} \mathrm{BrN}_{4} \mathrm{O}_{3} \mathrm{~S}$ & 429.25 & Orang & 65 & $120-122$ \\
5 & $\mathrm{C}_{18} \mathrm{H}_{11} \mathrm{ClN}_{4} \mathrm{O}_{3} \mathrm{~S}$ & 398.82 & Yellow & 75 & $143-145$ \\
6 & $\mathrm{C}_{18} \mathrm{H}_{11} \mathrm{BrN}_{4} \mathrm{O}_{3} \mathrm{~S}$ & 443.27 & Yellow & 77 & $138-140$ \\
7 & $\mathrm{C}_{18} \mathrm{H}_{11} \mathrm{ClN}_{4} \mathrm{OS}$ & 366.82 & Dark orang & 70 & $233-235$ \\
8 & $\mathrm{C}_{18} \mathrm{H}_{11} \mathrm{BrN}_{4} \mathrm{OS}$ & 411.28 & Dark orang & 70 & $225-227$ \\
9 & $\mathrm{C}_{14} \mathrm{H}_{9} \mathrm{ClN}_{4} \mathrm{OS}$ & 316.77 & Dark red & 75 & $184-186$ \\
10 & $\mathrm{C}_{14} \mathrm{H}_{9} \mathrm{BrN}_{4} \mathrm{OS}$ & 361.22 & Red & 76 & $177-179$ \\
\hline
\end{tabular}

Table 2. Spectral data of the compounds $(1-10)$

\begin{tabular}{|c|c|c|}
\hline Compounds No. & IR $\left(\mathrm{cm}^{-1}\right)$ & 1H-NMR $(\delta$, ppm) \\
\hline 1 & $\begin{array}{c}3421,3332\left(\mathrm{NH}_{2}\right) ; 1612(\mathrm{C}=\mathrm{N}) ; 653(\mathrm{~S}- \\
\mathrm{C})\end{array}$ & $6.94 \mathrm{~s},\left(2 \mathrm{H} ; \mathrm{NH}_{2}\right) ; 7.5-7.99(\mathrm{dd}, 2 \mathrm{H}, \mathrm{Ar}-\mathrm{H})$ \\
\hline 2 & $\begin{array}{c}3419,3330\left(\mathrm{NH}_{2}\right) ; 1615(\mathrm{C}=\mathrm{N}) ; 642(\mathrm{~S}- \\
\mathrm{C})\end{array}$ & $6.99 \mathrm{~s},\left(2 \mathrm{H} ; \mathrm{NH}_{2}\right) ; 7.4-8.02(\mathrm{dd}, 2 \mathrm{H}, \mathrm{Ar}-\mathrm{H})$ \\
\hline 3 & $\begin{array}{l}1678 \text { (carbonel, lactone); } 3289(\mathrm{O}-\mathrm{H}) \\
1151(\mathrm{C}-\mathrm{O}) ; 1613(\mathrm{C}=\mathrm{N}) ; 625(\mathrm{~S}-\mathrm{C})\end{array}$ & $\begin{array}{c}5.5(\mathrm{~s}, 1 \mathrm{H}: \mathrm{OH}) ; 7.4-8.02(\mathrm{dd}, 2 \mathrm{H}, \mathrm{Ar}-\mathrm{H}) ; 7.42-7.84(\mathrm{~m}, 4 \mathrm{H}, \\
\text { Ar-H })\end{array}$ \\
\hline 4 & $\begin{array}{c}1675 \text { (C=O, lactone); } 3290(\mathrm{O}-\mathrm{H}) ; 1150 \\
(\mathrm{C}-\mathrm{O}) ; 1610(\mathrm{C}=\mathrm{N}) ; 621(\mathrm{~S}-\mathrm{C}) \\
3193(\mathrm{O}-\mathrm{H}) ; 1685(\mathrm{C}=\mathrm{O}, \text { lactone }) ; 1141\end{array}$ & $\begin{array}{c}\text { 6.1( s,1H: OH }) ; 7.6-7.9(\mathrm{dd}, 2 \mathrm{H}, \mathrm{Ar}-\mathrm{H}) ; 7.40-7.79(\mathrm{~m}, 4 \mathrm{H} \\
\mathrm{Ar}-\mathrm{H})\end{array}$ \\
\hline 5 & $\begin{array}{c}\text { (C-0); } 2968 \text { (aliphatic C-H) } 1619 \\
\text { (C=N); } \\
635(\mathrm{~S}-\mathrm{C})\end{array}$ & $\begin{array}{c}2.39\left(\mathrm{~s}, 3 \mathrm{H}_{1} \mathrm{CH}_{3}\right) ; 5.29(\mathrm{~s}, 1 \mathrm{H}: \mathrm{OH}) ; 7.4-8.01(\mathrm{dd}, 4 \mathrm{H}, \mathrm{Ar}- \\
\mathrm{H}) ; 6.7-7.6(\mathrm{~m}, 2 \mathrm{H}, \mathrm{Ar}-\mathrm{H}) ; 6.62(\mathrm{~s}, 1 \mathrm{H}, \mathrm{Ar}-\mathrm{H})\end{array}$ \\
\hline 6 & $\begin{array}{c}3195(\mathrm{O}-\mathrm{H}) ; 1690(\mathrm{C}=\mathrm{O}, \text { lactone }) ; 1139 \\
\text { (C-O); } 2970 \text { (aliphatic C-H) } 1621 \\
(\mathrm{C}=\mathrm{N}) ; \\
629(\mathrm{~S}-\mathrm{C})\end{array}$ & $\begin{array}{c}2.4\left(\mathrm{~s}, 3 \mathrm{H}, \mathrm{CH}_{3}\right) ; 5.23(\mathrm{~s}, 1 \mathrm{H}: \mathrm{OH}) ; 7.4-7.95(\mathrm{dd}, 4 \mathrm{H}, \mathrm{Ar}- \\
\mathrm{H}) ; 6.8-7.5(\mathrm{~m}, 2 \mathrm{H}, \mathrm{Ar}-\mathrm{H}) ; 6.59(\mathrm{~s}, 1 \mathrm{H}, \mathrm{Ar}-\mathrm{H})\end{array}$ \\
\hline 7 & $3278(\mathrm{O}-\mathrm{H}) ; 1622(\mathrm{C}=\mathrm{N}) ; 626(\mathrm{~S}-\mathrm{C})$ & $\begin{array}{c}\text { 5.32( s,1H: OH); } 7.55-7.9(\mathrm{dd}, 4 \mathrm{H}, \mathrm{Ar}-\mathrm{H}) ; 6.98-8.06(\mathrm{~m}, \\
\text { Ar-H) }\end{array}$ \\
\hline 8 & $3280(\mathrm{O}-\mathrm{H}) ; 1619(\mathrm{C}=\mathrm{N}) ; 621(\mathrm{~S}-\mathrm{C})$ & $\begin{array}{c}5.4(\mathrm{~s}, 1 \mathrm{H}: \mathrm{OH}) ; 7.49-7.8(\mathrm{dd}, 4 \mathrm{H}, \mathrm{Ar}-\mathrm{H}) ; 6.85-8.02(\mathrm{~m}, \mathrm{Ar}- \\
\mathrm{H})\end{array}$ \\
\hline 9 & $3195(\mathrm{O}-\mathrm{H}) ; 1624(\mathrm{C}=\mathrm{N}) ; 619(\mathrm{~S}-\mathrm{C})$ & $\begin{array}{c}5.5 \text { (s,1H: OH); } 7.57-8.01(\mathrm{dd}, 4 \mathrm{H}, \mathrm{Ar}-\mathrm{H}) ; 7.51- \\
\text { 7.81(dd,4H, Ar-H) }\end{array}$ \\
\hline 10 & $3198(\mathrm{O}-\mathrm{H}) ; 1620(\mathrm{C}=\mathrm{N}) ; 620(\mathrm{~S}-\mathrm{C})$ & $\begin{array}{c}\text { 5.6(s,1H: OH); } 7.4-7.9(\mathrm{dd}, 4 \mathrm{H}, \mathrm{Ar}-\mathrm{H}) ; 7.55-7.80(\mathrm{dd}, 4 \mathrm{H}, \\
\mathrm{Ar}-\mathrm{H})\end{array}$ \\
\hline
\end{tabular}




\section{Al-Nahrain Journal of Science}

ANJS, Vol.23 (2), June, 2020, pp. 33 - 38

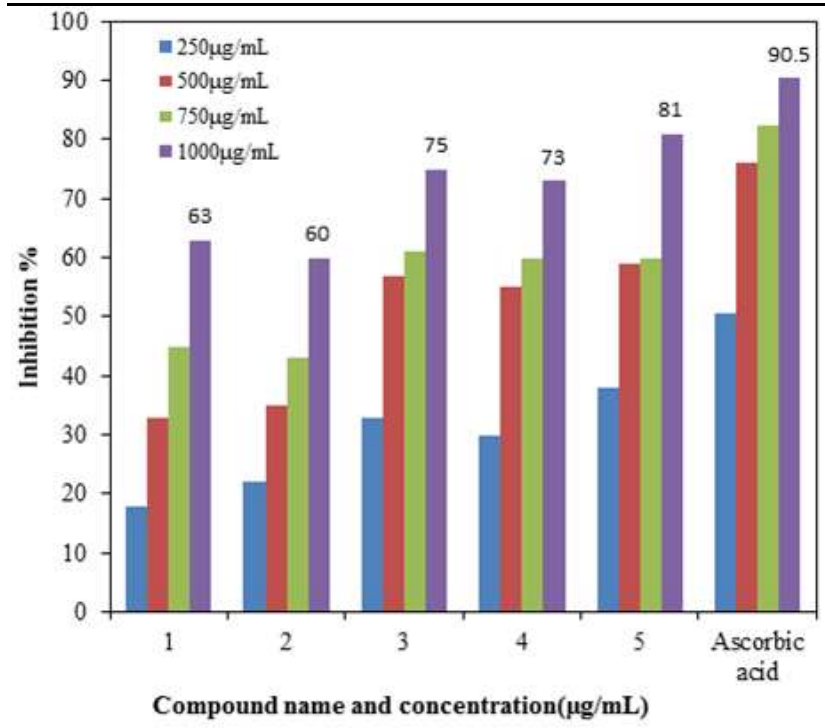

Figure 1. Compound reaction 1-5 with DPPH

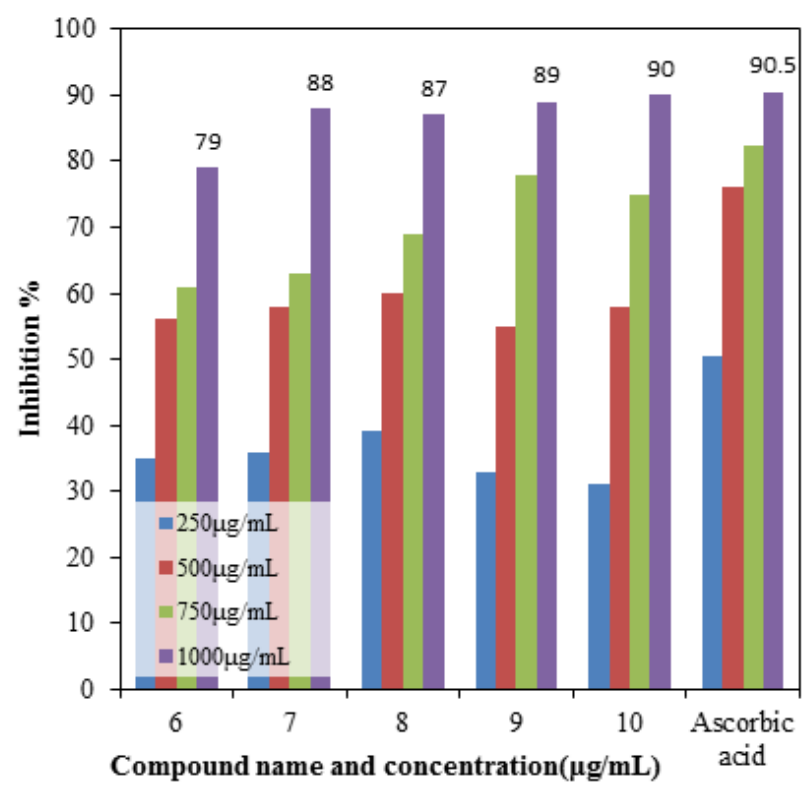

Figure 2. Compound reaction 6-10 with DPPH

\section{Conclusions}

In high to reasonable yields $(20 \%-90 \%)$, a series of new cyclic compounds based on 1,3,4-thiadiazol was successfully synthesized. Spectral analysis carried out by IR, 1H-NMR, Confirmed the statement structures of the new compounds. The tests of the products ' antioxidant activity showed that some of the newly synthesized compounds displayed promising activity.

\section{References}

[1] Al-Amiery, A. A.; Kadhum, H. A. A.; Obayes, R. H.; Mohamad, B. A.; "Synthesis and Antioxidant Activities of Novel 5-Chlorocurcumin, Complemented by Semiempirical Calculations"; Bioinorg. Chem. Appl., 1-7, 2013.

[2] Al-Amiery, A. A.; Al-Majedy, K. Y.; Ibrahim, H. H.; Al-Tamimi, A. A.; "Antioxidant, Antimicrobial and Theoretical Studies of the Thiosemicarbazone Derivative Schiff Base 2-(2-Imino-1- MethylImidazolidin-4 Ylidene) Hydrazine-CarboThioamide (IMHC)". Org. Med. Chem. Lett. 2(4),17, 2012.

[3] Cacic, M.; Molnar M.; "Design, Synthesis and Characterization of Some Novel 3-Coumarinyl-5 Aryliden-1,3-Thiazolidine-2,4-Diones and their Antioxidant Activity"; Z. Naturforsch 66(b), 177183, 2011.

[4] Foti, M.; Piattelli, M.; Baratta, M. T.; Ruberto, G.; "Flavonoids, Coumarins, Antioxidants in a Micellar System, Structure-Activity and Cinnamic Acids as Relationship"; J. Agric. Food Chem. 44, 497-501, 1996.

[5] Fylaktakidou, K. C.; Hadjipavlou-Litina, D. J.; Litinas, K. E.; Nikolaides, D. N.; "Natural and Synthetic Coumarin Derivatives with AntiInflammatory / Antioxidant Activities"; Curr. Pharm. Des. 10, 3813-3833,2004.

[6] Bailly, F.; Maurin, C.; Teissier, E.; Vezina, H.; Cotelle, P.; " Antioxidant Properties of 3Hydroxycoumarin Derivatives"; Bioorg. Med. Chem. 12, 5611-5618,2004.

[7] Anand P.; Singh B.; Singh N. A.; "Review on Coumarins as Acetylcholinesterase Inhibitors for Alzheimer's Disease"; Bioorg Med Chem. 20(3):1175-80,2012.

[8] Al-Majedy, Y. K.; Al-Duhaidahawi, D. L.; Al-Azawi, K. F.; Kadhum, A. A. H.; Al-Amiery, A. A.; Mohamad, A. B.; "Coumarins as Potential Antioxidant Agents Complemented with Suggested Mechanisms and Approved by Molecular Modeling Studies"; Molecules 21(2), 1-11, 2016.

[9] Liaras, K.; Geronikaki, A.; Glamoc, 1. J.; Ciric, A., Sokovic, M.; "Thiazole-Based Chalcones as Potent Antimicrobial Agents.Synthesis and Biological Evaluation"; Bioorg. Med. Chem. 19, 3135-3140, 2011.

[10] Vicini, P.; Geronikaki, A.; Anastasia, K.; Incertia, M.; Zani, F.; "Synthesis and Antimicrobial Activity of Novel 2-Thiazolylimino-5- Arylidene-4Thiazolidinones"; Bioorg. Med. Chem. 14, 38593864, 2006.

[11] Sies, H.; "Oxidative Stress: Oxidants and Antioxidants"; Exp. Physiol. 82(2), 291-295, 1997.

[12] Abdalla, A. E.; Roozen, J. P.; "Effect of Plant Extracts on the Oxidative Stability of Sunflower Oil and Emulsion"; Food Chem. 64, 323-329, 1999. 


\section{Al-Nahrain Journal of Science \\ ANJS, Vol.23 (2), June, 2020, pp. 33 - 38}

[13] Mishra, P.; Jatav, V.; Kashaw, S. K.; "Some Novel 2-Methyl-3-(1'3'4'-Thiadiazolyl)-4- $(3 \mathrm{H})$

Quinazolinones with Anticonvulsant and CNS Depressant Activity"; J. Indian Chem. Soc. 83, 1165-1170, 2006.

[14] Abdou, O. A.; Sobhi, M. G ;Nadia, A. A.; Saher, M. K.; " Synthesis of New 3-Heteroarylindoles as Potential Anticancer Agents"; J. Molec. 21, 929935, 2016.

[15] Al-Amiery, A.; Al-Majedy, A.; Al-Duhaidahawi, D.; Kadhum, A. A.; Mohamad, A. B.; "Green Antioxidants: Synthesis and Scavenging Activity of Coumarin-Thiadiazoles as Potential Antioxidants Complemented by Molecular Modeling Studies"; Free Rad. Antioxid. 6(2), 173-177, 2016.

[16] Al-Amiery, A. A.; Al-Majedy, Y. K.; Kadhum, A. A. H.; Mohamad, A. B.; "Hydrogen Peroxide Scavenging Activity of Novel Coumarins Synthesized Using Different Approaches", PLoS ONE 10(7), e0132175, 1-9 2015.

[17] Al-Amiery, A. A.; Al-Majedy, Y. K.; Kadhum, A. A. H.; Mohamad, A. B.; "Novel macromolecules derived from coumarin: synthesis and antioxidant activity"; Sci. Rep. 5, 11825, 2015.

[18] Xue. H.; Lu, X.; Zheng, P.; Liu, L.; Han, C.; Hu, J.; Liu, Z.; Ma, T.; Li, Y.; Wang, L.; Chen, Z.; Liu, G.; "Highly Supperssing Wild-Type HIV-1 and Y181C Mutant HIV-1 Strains by 10-Chloromethyl11demethyl-12 oxocalanolide A with Druggable Profile"; J. Med. Chem. 53(3), 1397-1401, 2010.
[19] Roussaki, M.; Kontogiorgis, C. A.; HadjipavlouLitina, D.; Hamilakis, S.; Detsi, A.; "A novel synthesis of 3 -aryl coumarins and evaluation of their antioxidant and lipoxygenase inhibitory activity"; Bioorg. Med. Chem. Lett. 20, 3889-3892, 2010.

[20] Najeebullah, K.; Samiullah, N.; Attiq-ur-Rehman, K.; Rasool, B. T.; Nazi, M.; Syed-Waheed, A. S.; Irshad, A.; Muhammad, A.; Abdul-Baqi, A.; "Determination of Antioxidants and Antimicrobial Activities of Platytaenia multicaule"; Al-Nahrain J. Sci. 22(4), 19-29, 2019.

[21] Ghufran, S. N.; Amer, H. A.; Najwa, S. A.; Wafaa, R. A.; "Evaluation of Estridiol and Some Antioxidant in Breast Cancer Iraqi Women"; $\mathrm{Al}^{-}$ Nahrain J. Sci. 21(1), 35-40, 2018.

[22] Ghufran, S. N.; Amer, H. A.; Najwa, S. A.; Wafaa, R. A.; "Evaluation of Estridiol and Some Antioxidant in Breast Cancer Iraqi Women"; $\mathrm{Al}^{-}$ Nahrain J. Sci. 21(1), 35-40, 2018.

[23] Hameed, S.; Ibraheem, H.; "Synthesis, Characterization and Biological Activity of Some Heterocyclic Compounds Containing Quinoline Molecule"; Al-Nahrain J. Sci. 23(1), 1-6, 2020. 